\title{
SPRAWOZDANIE Z IV MIĘDZYNARODOWEJ INTERDYSCYPLINARNEJ KONFERENCJI NAUKOWEJ POD NAZWA „PRAWO NATURALNE I PRAWO STANOWIONE FUNDAMENTEM POKOJU I SPRAWIEDLIWOŚCI W ŚWIECIE"
}

DOI: http://dx.doi.org/10.12775/TiCz.2019.022

W dniach 12 i 13 kwietnia 2019 roku w gmachu Wyższego Seminarium Duchownego w Kaliszu odbyła IV międzynarodowa interdyscyplinarna konferencja naukowa zatytułowana „Prawo naturalne i prawo stanowione fundamentem pokoju i sprawiedliwości w świecie”. Głównymi organizatorami konferencji byli ks. prof. UAM dr hab. Dariusz Kwiatkowski we współpracy z kl. Jakubem Bogackim. Konferencja objęta była patronatem Ministerstwa Sprawiedliwości oraz Wydziału Teologicznego Uniwersytetu im. Adama Mickiewicza w Poznaniu. Cennym jest zauważenie, że instytucje te wykazały duże wsparcie dla organizatorów konferencji, a dla prelegentów zorganizowane zostały upominki ufundowane przez Ministerstwo Sprawiedliwości. W konferencji brali udział prelegenci reprezentujący rozmaite ośrodki naukowe. Najliczniejsza grupa pośród nich wywodziła się z polskich uczelni takich, jak Uniwersytet im. Adama Mickiewicza w Poznaniu, Uniwersytet im. Kardynała Stefana Wyszyńskiego w Warszawie z filiami w Arcybiskupim Wyższym Seminarium Duchow- 
nym w Białymstoku i Gdańsku, Politechnika Wrocławska, Uniwersytet Wrocławski. Nie zabrakło także przedstawicieli uczelni zagranicznych pochodzących z Ukrainy, Serbii, Chorwacji i Szwajcarii reprezentujących uniwersytety: Accademia Alfonsiana, University of Belgrad, Universität Luzern, Université de Fribourg. Konferencja ta była już czwartą z kolei konferencji skupiających się wokół zagadnień oscylujących wokół teologii, ujętych w interdyscyplinarnym kluczu. Tym razem tematyka koncentrowała się jednak w dużej mierze na zagadnieniach prawnych. Podobnie jak wcześniejsze konferencje okazały się niezwykłe cenne dla świata nauki, podobnie i niniejsza konferencja może mieć niemały wkład w rozwój dyscyplin teologicznych. Zapraszam do zapoznania się z krótkim sprawozdaniem z przebiegu konferencji.

Konferencja zainaugurowana została mszą świętą celebrowaną w głównej kaplicy kaliskiego seminarium. Przewodniczył jej ks. dr Waldemar Graczyk. Po zakończonej mszy świętej odbyła się uroczysta kolacja, podczas której wszyscy prelegenci zostali oficjalnie przywitani. Następnie wszyscy biorący udział w konferencji udali się do auli seminarium, gdzie mogli wysłuchać wykładu inauguracyjnego, który wygłosił ks. dr Waldemar Graczyk, a którego temat brzmiał „Etyka uniwersalna: marzenie, konieczność, utopia? Refleksje teologiczno-moralne na kanwie dokumentu Międzynarodowej Komisji Teologicznej w poszukiwaniu etyki uniwersalnej: Nowe spojrzenie na prawo naturalne”. Wykład ten poruszał ważne kwestie dotyczące ujęć etycznych. Ks. Graczyk oparł się na dokumencie Międzynarodowej Komisji Teologicznej, na bazie którego próbował nakreślić elementy nieodłączne dla dziedziny etyki uniwersalnej, której to entuzjaści, pomimo faktu odrzucenia objawienia, muszą wiedzieć, iż dla etyki pewne punkty są istotowe i inherentnie zeń związane ze względu na prawo naturalne i wywodzące się z niego zasady, które są nadrzędne w stosunku do jakichkolwiek ustaleń i praw ludzkich. Wykład ten nagrodzony został brawami, które świadczyły o dobrym przyjęciu go przez odbiorców. Zostali oni zapewne pozytywnie „nastrojeni” na udział w dalszej części konferencji.

O godzinie 19.30 rozpoczął się pierwszy blok wykładowy, który prowadził kl. Witold Morozowicz. Jako pierwszy prelegent swój referat przedstawiał dk. lic. Tobiasz Stasiński z ASD Białystok. Tytuł jego referatu brzmiał „Implikacje na rzecz pokoju i sprawiedliwości w świetle prawa 
naturalnego św. Jana Pawła II”. Dk. Tomasz, bazując na encyklice Veritatis Splendor, starał się przedstawić zależność między prawem cywilnym a prawem naturalnym. Przedstawił on także koncepcję sumienia, które winno opierać się na prawdzie wywodzącej się z prawa naturalnego i zakonkludował stwierdzeniem, że „Prawo Boże jest gwarancją pokoju”. Drugim prelegentem w tym bloku był Jakub Nowrot z Uniwersytetu Wrocławskiego. Zaprezentował on referat „Związki osób homoseksualnych w polskim porządku prawnym”, w którym dokonał on analizy polskiego systemu prawnego w kontekście możliwości zawierania małżeństw przez pary jednopłciowe. W referacie tym wysnuł on wniosek, że w chwili obecnej takie małżeństwa nie są legalne, jednak w przyszłości może to ulec zmianie. Trzeci referat w tym bloku przygotował inż. Damian Brzoza z Politechniki Wrocławskiej. Jego temat brzmiał „Pokaż mi swoje dane, a powiem ci kim jesteś. Data science - fundament pokoju czy narzędzie inwigilacji obywateli?". W referacie tym inż. Brzoza prezentował w jaki sposób koncerny wykorzystują pobierane i wysyłane przez użytkowników Internetu dane. Spróbował także przekazać słuchaczom wiedzę jak świadomie $\mathrm{z}$ danych tych korzystać, by nie dać się inwigilować. Referat zakończył on postawieniem retorycznego pytania zawartego w tytule, zachęcając przez to słuchaczy do odpowiedzialnego korzystania $z$ danych $\mathrm{w}$ celu budowania sprawiedliwości w świecie. Ostatnim prelegentem prezentującym w tym bloku swój referat był ks. mgr lic. Roman Woźniak z Accademia Alfonsiana. W referacie „Czym jest wojna na Ukrainie i jakie zagrożenie ona nosi dla Europy” próbował on przedstawić po krótce przyczyny wojny toczącej się na Ukrainie i co może z niej wyniknąć w przyszłości. Był to bardzo cenny referat, ponieważ Ks. Woźniak, jako rodzimy Ukrainiec, ma szeroki pogląd w tej kwestii, a jego przemyślenia przyczyniły się do lepszego zrozumienia owej sytuacji przez odbiorców. Pierwszy blok wykładowy zakończył się dyskusją. Padało wiele pytań, na które prelegenci z chęcią odpowiadali. Zainteresowanie było jednak tak duże, że nie wszyscy zdążyli zapytać o interesujące ich kwestie. Mieli jednak ku temu możliwość na spotkaniu integracyjnym, które odbyło się o godzinie 21.30. Pierwszy dzień konferencji zapisał się w pamięci uczestników bardzo pozytywnie.

W drugi dzień konferencji jej uczestnicy mogli wziąć udział w porannej mszy świętej, natomiast konferencja rozpoczęła się o godzinie 9.00 
wykładem wprowadzającym ks. prof. UAM dr hab. Dariusza Kwiatkowskiego pod tytułem „Wierność prawu liturgicznemu wiernością Chrystusowi”. Ks. prof. Kwiatkowski w swoim wykładzie wysnuł tezę, w której założył, że przestrzeganie praw dotyczących kultu ma swoje odzwierciedlenie w duchowości celebransa. W wykładzie wskazywał on na zagrożenie nadużyć liturgicznych i wielkie niebezpieczeństwo duchowe, jakim jest swoistego rodzaju niedbałość o piękno liturgii, jej formę, dokładność gestów i słów. Z uwagi na fakt, iż dużą grupę słuchaczy stanowili klerycy, ksiądz profesor zachęcił ich do wielkiej dbałości o „szczegóły” celebrowania liturgii w ich przyszłej posłudze kapłańskiej.

Wykład ten wprowadził słuchaczy w drugi blok konferencji, a jako pierwszy prelegent swój referat przedstawił Nikola Dzavric - prawosławny kleryk pochodzący z Serbii i studiujący na University of Belgrad. Kl. Dzavric mówił o „Kryzysie kanonicznym w Ukraińskim Kościele Prawosławnym"'; opisywał on historię Kościoła Ukraińskiego, przedstawił zagadnienie autokefaliczności, wysnuł kwestię sporów wobec patriarchy Bartłomieja i Stolicy Konstantynopolitańskiej. W referacie tym zaakcentował jednak pytanie, co dalej wydarzy się w Kościele Prawosławnym, sugerując poniekąd, że stoi on na granicy schizmy. Temat ten był szeroko podejmowany w dalszych dyskusjach. Drugim prelegentem w tym bloku był pan Wiktor Paluch, który reprezentując Politechnikę Wrocławską, przedstawił referat pt. „Czy własność intelektualna powinna mieć granice?”. Głównym tematem referatu Pana Palucha było zagadnienie prawa patentowego. Przedstawiał on różne ujęcia tej kwestii w zależności od danego kraju. Opisywał także możliwości oszustwa, którego dopuszczają się duże koncerny, poprzez blokowanie wejścia na rynek nowych technologii poprzez nadawanie im prawa patentowego i tzw. „zamrażanie”. $\mathrm{Na}$ koniec postawił on pytanie, czy tego typu prawo jest zgodne $\mathrm{z}$ moralnością - prawem naturalnym ludzkości do rozwoju. Kleryk Mateusz Grabowski przybyły z Wyższego Seminarium Duchownego w Gdańsku jako trzeci w tym bloku prezentował swój referat. Temat jego brzmiał „Porządek prawny postulowany w nauczaniu społecznym kard. Stefana Wyszyńskiego na podstawie wybranych dzieł”. W referacie tym mogliśmy zapoznać się ze zbiorem idei kard. Wyszyńskiego dotyczących porządku

\footnotetext{
${ }^{1}$ Org. A canonical crisis in the Ukrainian Orthodox Church.
} 
prawnego. Ujęcie zagadnienia osadzone było w oryginalnym kontekście wypowiedzi kardynała mianowicie walki z komunizmem. Na podstawie wysłuchanego referatu możemy dość do wniosku, że istotą myśli kard. Stefana Wyszyńskiego było swoiste ujęcie zasady antropicznej w kontekście prawnym. Mianowicie prawo ma służyć człowiekowi i przyczyniać się do jego wzrostu poprzez zapewnianie ładu społecznego. Jako ostatni w tym bloku swój referat wygłosił inż. Michał Czuba studiujący na Politechnice Wrocławskiej. Referat ten był zatytułowany „Regulacje prawne systemów opierających się o metody sztucznej inteligencji - wymóg bezpieczeństwa czy hamowanie rozwoju cywilizacyjnego?". Tak problemowo postawiona kwestia została przez inż. Czubę wyłożona na podstawie zaprezentowania działania sieci neuronowych i związanych z nimi obostrzeń prawnych dotyczących możliwości ich wykorzystywania na różnych płaszczyznach. Drugi blok konferencji zakończył się tym wykładem, po czym przeznaczony był czas na dyskusję. Szczególnie ciekawym dla słuchaczy był pierwszy referat. Śmiem przypuszczać, że wyniknęło to z pewnej różnicy kulturowej i chęci pogłębienia wiedzy o prawosławiu. Pytań było jednak tak dużo, że dyskusja musiała zostać przeniesiona do stołu kawowego, gdzie zainteresowani poszczególnymi kwestiami mogli już bezpośrednio porozmawiać o nich z prelegentami.

O godzinie 11:30, zaraz po przerwie kawowej, rozpoczął się trzeci, ostatni, blok wykładowy konferencji. Zainaugurował go pan Matej Veres Chorwat studiujący na Uniwersytecie w Luzernie. Zaprezentował on biblijno-prawne opracowanie zagadnienia sakramentu małżeństwa. Sporą część wykładu poświęcił terminologii, jaką w ciągu wieków odnoszono do małżonków i sakramentu. Zwrócił uwagę na fakt, iż od czasów II Soboru Watykańskiego małżeństwo katolickie nazywa się przymierzem, a nie umową. Myśl podjętą przez pana Veresa kontynuował kleryk Gabriel Kuhn, który przybył do nas ze Szwajcarii, a studiujący na co dzień na Uniwersytecie we Fryburgu. W czasie swego wystąpienia ukazał niepowtarzalny charakter małżeństwa katolickiego. To Bóg scala związek kobiety i mężczyzny, podnosząc go do rangi sakramentu. Odpowiadając na pytanie zawarte w tytule wystąpienia, prelegent stwierdził, że małżeństwo katolickie jest potrzebne do szczęścia. Trzecim prelegentem w tym bloku był inż. Mateusz Zimoch z Politechniki Wrocławskiej, który zaprezentował nam referat pt. „Pojazdy autonomiczne a prawo o ruchu drogowym i moral- 
ność w zagadnieniach sztucznej inteligencji”. W referacie tym inż. Zimoch oprał się na przykładzie samochodu autonomicznego „Tesla”. Rozważał on problem dokonywania wyborów przez ten samochód, czyli w praktyce wybierania przezeń wariantów zachowania wgranych przez programistę, w sytuacjach skrajnych, jakim jest np. alternatywa - samochód wjeżdża na zderzenie czołowe narażając kierowcę albo wjeżdża w przystanek pełen ludzi ocalając kierowcę, ale zabijając ludzi. W wykładzie tym mogliśmy przyjrzeć się bliżej dylematom, z jakimi spotykają się na co dzień programiści, ponieważ $\mathrm{w}$ tego typu problemach prawo cywilne staje się bezużyteczne, a pomóc może jedynie sumienie - prawo naturalne poznane w duszy przez każdego człowieka. Jako gospodarz ostatni wykład całej konferencji wygłosił kl. Jakub Bogacki z Wyższego Seminarium w Kaliszu. Zaprezentował on referat zatytułowany "Codex Canonum Ecclesiarum Orientalium. Powstanie - znaczenie - interpretacje”. Prelegent wskazał, że nie tylko Kościół łaciński posiada Kodeks Prawa Kanonicznego, gdyż za czasów pontyfikatu św. Jana Pawła II promulgowano analogiczny dokument dla katolickich Kościołów wschodnich. Fakt ten sprawia, że niewątpliwie Papież-Polak zostanie zapamiętany przez historię jako wielki ustawodawca. Konferencja zakończyła się uroczystym obiadem.

IV Międzynarodowa Konferencja Naukowa w Kaliszu została zakończona. Spotkała się ona z pozytywną reakcją słuchaczy, którzy chwalili usłyszane treści. Także prelegenci cieszyli się z miłej atmosfery, która sprzyjała mówieniu, ale także dziękowali za aktywny udział i uwagę słuchaczy. Szczególne słowa uznania należą się ks. prof. UAM dr hab. Dariuszowi Kwiatkowskiemu za zorganizowanie, już po raz czwarty, takiej konferencji oraz klerykowi Jakubowi Bogackiemu. Warto zaznaczyć obecność księdza biskupa dr. Łukasza Buzuna, który skierował do obecnych krótkie słowo. Ponadto gospodarz kaliskiego seminarium - ks. mgr lic. Marcin Załężny brał czynny udział w całej konferencji, odznaczał się otwartością na gości i serdecznością w przyjęciu. Całą konferencję można uznać za nad wyraz udaną. Korzystając z okazji, już teraz chcemy zaprosić szanownych Czytelników na kolejną w serii V Międzynarodową Konferencję Naukową w Kaliszu. Choć jej dokładna data nie jest jeszcze określona, będziemy niezwykle zaszczyceni, mogąc gościć Was w Kaliszu. 